\title{
Effect of Chlorpyrifos and Neem seed extract (Azadirechtein) on hepatopancreatic cellular structures of the freshwater crayfish Procambarus clarkii
}

\author{
Abdel menam, K.; Mahmoud, A. S.; Zeinab, Z. K. and Radwa, M. S. \\ Department of Zoology, Faculty of Science, Zagazig University, Zagazig, Egypt.
}

\section{ABSTRACT}

Histological and ultrastructural studies on the normal structures of hepatopancreas of $P$. clarkii showed three main cell types, secretory, absorptive and fibrillar cells. The ultrastructural alterations in the hepatopancreas of the red swamp crayfish P. clarkii exposed to sublethal concentrations of Chlorprifos and neem seed extract (Azadirechtein) pesticides were studied. LC $_{25}$ of Chlorpyrifos (0.0075 ppm) produced deformation of the apical surface of absorptive cell, dispersedmicrovilli, mitochondrial swelling with ballooned cristae, deformed cisternae of RER, lytic and vacuolated cytoplasm and pyknosis of nuclei. On the other hand, $\mathrm{LC}_{25}$ of Azadirechtein (4.99 ppm) caused deformation of mitochondria with the sparce of their cisternae, fragmentation of microvilli, ruptured RER beside the presence of autophagic vacuole containing dark granules and finally bizzar nuclei having segregated nucleoli and irregular clumps of their chromatin. Chlorpyrifos was found to be more toxic than Azadirechtein on P. clarkii.

Keywords: Procambarus clarkii, Chlorpyrifos, Azadirechtein, hepatopancreas, ultrastructure.

\section{INTRODUCTION}

Procambarus clarkii was introduced in the early 1980's into Egypt after a trial for its aquaculture that eventually failed and some them were thrown into the Nile. $P$. clarkii was greatly spread all over the River Nile, its branches and ditches through the Delta, Cairo and Giza (Ibrahim et al., 1995). They were leaved without control and caused a lot of damage to the fisheries of the Nile possibly by eating the eggs and young fish beside damaging the nets of fishermen as well ascausing serious damages to irrigation systems as a result of their burrowing activities (Soliman et al., 1998b). Considerable effort has been paid to control its dispersal with pesticides (Lang and Chang, 1967; Hobbs et al., 1989).

Chlorpyrifos is an organophosphorous pesticide that is commercially used to control foliar insects that affect agricultural crops and subterranean termites (Rusyniak and Nanagas, 2004; Rao et al., 2005). It has been used globally as an insecticide to control pests agriculturally and in the home because of its high insecticidal property, low mammalian toxicity, less persistence and rapid biodegradability in the environment (Tripathi et al., 2000 and Singh et al., 2010). Chlorpyrifoshas a very toxic effecton aquatic invertebrates especially crustaceans (Bharathi \& Sandeep, 2005; Li et al., 2006). The toxicity of Chlorpyrifos is exerted through the inhibition of acetylcholinestrase (AchE). Repeated exposures to this insecticide, such inhibition may cause damage to aquatic organisms (Kwong, 2002; Barata et al. 2004).

Reduction of the environmental problems caused by the use of synthetic chemicals and the growing need for alternative methods of crayfish control that minimize this damage, there has been extensive research on pest control by natural 
pesticides. Azadirechtein wasone of the most promising natural compounds extracted from theneem tree (Azadirachtaindica) that has antiviral, antibacterial and antifungal properties (Isman et al., 1990; Harikrishnan et al., 2003). It was generally considered to be less harmful to the environment than other more commonly used pesticides (Mordue and Blackwell, 1993). Azadirechtein has low toxicity against non-target organisms (fishes, mammals and beneficial invertebrates) and low persistence in the environment (Schmutterer, 1995; Wan et al., 1996; Isman, 1997 and Schaaf et al., 2000). Its use is now considered for arthropod control (Jimenez et al., 1998). The hepatopancreas fulfills a key role in the temporary storage of exoskeletal calcium, phosphate, glycogen and lipids during the different phases of the moultcycleand represents a corner stone in the body metabolism (Mercado-Allen, 1991; Nicol et al., 1992; Scott-Fordsmand and Depledge, 1997; Wheatly, 1997). It is considered as the most sensitive organ to toxicants and the main site of accumulation and detoxification in crayfish bodies (Neff et al., 1976; Lauren \& Rice, 1985 and Jaiswal \& Sanojini, 1990). The hepatopancreatic tissue was chosen in the present study as a suitable and special model for studying the effect of Chlorpyrifos and Azadirechtein pesticides.

The present study aimed to shed the light on the toxic effect of sublethal concentrations $\left(\mathrm{LC}_{25}\right)$ of Chlorpyrifos $(0.0075 \mathrm{ppm})$ and Azadirechtein $(4.99 \mathrm{ppm})$ for 7 days onthe cellular structure of hepatopancreas of P. clarkii compared with the control.

\section{MATERIALS AND METHODS}

\section{1- Tested pesticides:}

Table 1: List of pesticides, their trade names, activeingredients, chemical names and structural formula.

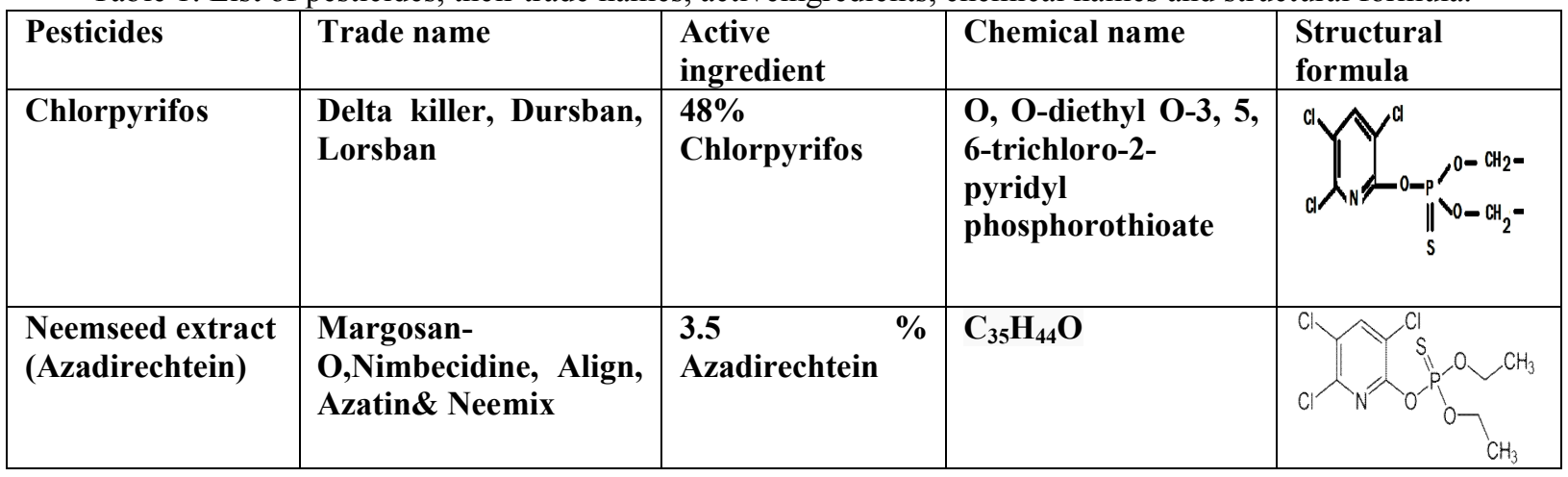

\section{2- Tested animals and acclimation procedures:}

Adults male $P$. clarkii (25-34 gm. average weight and 9-11 cm total length) were collected from Bany Helal irrigation canal, Sharkia Governorate during September 2014. The collected specimens were transported alive to the laboratory in a well-areated large plastic containers $(30 \times 50 \times 30 \mathrm{~cm})$. They were adapted for laboratory conditions at a temperature $25^{\circ} \mathrm{C}$ and a $12: 12 \mathrm{~h}$ light-dark regime. Water was changed every day and crayfish were fed on carrot.

\section{3- Test solution:}

Test solutions of Chlorpyrifos and Azadirechtein were prepared from stock solution which has been prepared by using distalled water as a solvent to give the following concentrations which were obtained by serial dilution of Chlorpyrifos 0.01 , 0.015, 0.02, $0.04 \mathrm{ppm}$ and for Azadirechtein 8, 10, 12, $14 \mathrm{ppm}$. 
Three replicates per each concentration were used to determine the $\mathrm{LC}_{50}$. Ten full mature male animals $(9-12 \mathrm{~cm})$ were placed in each aquarium. An equal number from males were left without treatment as a check control. Experiments were checked at $24 \mathrm{~h}$ intervals up to $96 \mathrm{hr}$. The dead crayfish were counted and reported. $\mathrm{LC}_{50}$ was determined according to Finney (1971) by the graphic method of the curve doseeffect, using the probit analysis. In the long - term exposure; half of the $96 \mathrm{hrsLC}_{50}$ of the tested pesticides was used and redosed every 4 days in a static renewal manner. Living animals, surviving the effect of the tested pesticides were sacrificed after 7 days of exposure. During chronic exposure times to the tested pesticides, feeding of animals was stopped.

Table 2: List of pesticides, their exposure time, LC50 and $\mathrm{LC}_{25}$

\begin{tabular}{|c|c|c|}
\hline \multirow{2}{*}{ Pesticides } & 96-hrs & 7-days \\
\hline & $\mathrm{LC}_{5}$ & LC \\
\hline Chlorpyrifos & 0.015 & 0.0075 \\
\hline Azadirechtein & 9.98 & 4.99 \\
\hline
\end{tabular}

\section{4- Light microscopy preparations:}

A group of $P$. clarkii specimens of control were dissected. The hepatopancreas of the dissected specimens were taken and fixedin $10 \%$ formalin for 24 hours and dehydrated through ascending series of ethanol. Tissues were embedded in paraffin wax andsections 4-6 $\mu \mathrm{m}$ thick were cut and stained with hematoxylin and eosinandmounted on a slide using Canda balsam and covered with a glass slip.

\section{5- Transmission electron microscopy preparations:}

Another group of both control and treated specimens were fixed in $2.5 \%$ glutraldehyde in $0.05 \mathrm{M}$ cocodylate buffer containing 0.15 sucrose at $\mathrm{pH} 7.2$ for 2 hours. Specimens were post fixed in $1 \%$ Osmium tetroxide with the same buffer at $0-4^{\circ} \mathrm{C}$ for one hour and washed again. The specimens were dehydrated in ascending ethanol series and finally embedded in Araldite of Epon. Blocks were sectioned with diamond ultramicrotome knifes. The semi-thin sections were stained with $1 \%$ toluidine blue. Ultra-thin sections stained with aqueous urinyl acetate and lead citrate and then examinedusing a Jeol Transmission Electron Microscopic at the regional center for Mycology and Biotechnology in El-Azhar University, Nasr city, Cairo, Egypt.

\section{RESULTS}

\section{1- Light microscopy examination of normal hepatopancreas of $P$. clarkii:}

The hepatopancreas was formed of numerous digestive tubules which communicate with the lumen of the mid gut and end blindly in the gland itself. The intertubular spaces are formed of connective tissues and blood vessels (Plate I, Fig .a). Each tubule has central lumen andwas formed of three types of cells, absorptive cell (AC), secretory cell (SC) and fibrillar cell (FC). Both secretory and absorptive cells were found to be more abundant than fibrillar cells (Plate I, Fig. b).

The absorptive cells were the most numerous cell types which were dark columnar in shape. The nucleus was centrally or basely located and has an apical brush border. The secretory cell was larger than absorptive cell and has have basely located nucleus $(\mathrm{N})$. A large irregular vacuole $(\mathrm{V})$ was found in its cytoplasm filled with acidophilic material (Plate I, Fig. b). The fibrillar cell was dark and scattered among absorptive and secretory cells but more concentrated among the secretory 
cells. A larger basely located nucleus $(\mathrm{N})$ and prominent nucleolus (NU) characterized the fibrillar cell (Fig.1.a and b).

\section{2- TEM examinations of normal hepatopancreas of $\boldsymbol{P}$. clarkii:}

The apical surface of absorptive cell was modified for food absorption as a brush border composed of numerous microvilli (MV).A straight filament (F) extends downwards from each microvillus into the apical cytoplasm . The cytoplasm contain a number of irregularly shaped mitochondria (M), which concentrated just below the apical surface of the cell (Plate II, Fig. a). The cytoplasm between the nucleus and the apex of the absorptive cells usually contains very small apical vesicle containing dense material and parallel tubules of rough endoplasmic reticulum (Plate II, Fig .b and c). The cytoplasm of secretory cell contain very thin layer of rough endoplasmic reticulum (RER) found in a perinuclear position and small number of mitochondria (Plate II, Fig .d).

The apical surface of fibrillar cell lacks a brush border and less number of mitochondria than the absorptive cell, the rough endoplasmic reticulum (RER) is massive and fills almost all the cell and the chromatic material (CM) appears granular and scattered throughout the nucleus with a concentration towards the nuclear membrane (NM) (Plate II, Fig .e and f).

\section{3- TEM examinations of hepatopancreas of $P$. clarkia exposed to $0.0075 \mathrm{ppm}$ of Chlorpyrifos:}

Plate III showed electron micrographs of hepatopancreas treated with $0.0075 \mathrm{ppm}$ Chlorpyrifos and it can be seen that deformed apical surface of absorptive cell with dispersed microvilli (Plate III, Fig a). Some rough endoplasmic reticulum (RER) has the form of short and thin cisternae, was in the form of concentric whorls and other are fragmented, presence of degenerated cellular debris and granules $(G)$ encapsulated within small vesicles (V) in their cytoplasm (Plate III, Fig a). Mitochondria (M) of the absorptive cell were swollen with the sparse of their cisternae (Plate III, Fig b).The cytoplasm of absorptive cells become granular, lost its density and being highly vacuolated (Plate III, Fig c). The nucleus of secretory cells become pyknotic with segregated nucleolus and their chromatin material (CM) appeared as dense masses near the nuclear membraneand their cytoplasm become lytic and fill with many vesicles(Plate III, Fig d).The nucleus of the absorptive cellbecome pyknotic with irregular nuclear envelop and their chromatein materials (CM) appear as electron dense aggregates along the inner nuclear envelop (Plate III, Fig e).

\section{4- TEM examinations of hepatopancreas of $P$. clarkia exposed to $4.99 \mathrm{ppm}$ of Azadirechtein:}

Electron micrographs show that microvilli of the absorptive cells are fragmented (Plate IV, Fig .a and b). Mitochondria were bizzar and characterized bythe sparse of its cisternae and lucent matrix (Plate IV, Fig .b). The cytoplasm become granular, losses its density and being highly vacuolated (Plate IV, Fig .a, b and c). It is also noted that the apices of cells contained degenerated cellular debris and granules $(\mathrm{G})$ encapsulated within small vesicles (V) in their cytoplasm, autophagicvacuole containing dark vesicles was noted (Plate IV, Fig .d). The rough endoplasmic reticulum of the fibrillar cell has the form of short, thin cisternae and also has the form of concentric whorls while others were fragmented. The chromatin materials of the nucleus (CM) appeared as dense masses scatter in the nucleoplasm and as irregular clumps near the inner nuclear envelop; the nuclear envelop was ruptured (Plate IV, Fig .e). 


\section{DISCUSSION}

The hepatopancreas represents the most important organ in the body metabolism of crayfish. It is considered to be the most sensitive organ to pollutants and toxicants and the main site of accumulation and detoxification in crayfish bodies (Neff et al., 1976; Lauren \&Rice, 1985 and Jaiswal \& Sanojini, 1990).

The present study showed clearly that there are three main cell types forming the digestive tubules of $P$. clarkii. These cells were the absorptive, secretory and fibrillar cells. This findings are in agreement with Abdel- Atti (2002) but disagree with Davis \& Burnett (1964), Bunt (1968), Stanier et al. (1968), Gibson \& Barker (1979), Papathanassiou \& King (1984), Trinadaha Babu et al. (1989) and Zilli et al. (2003) who mentioned that hepatopancrase has four types of cells: E-cells (embryonic cells), R-cells (absorptive cells), F-cells (fibrillar cells ) and B-cells (secretory cells). R-cells (absorptive cells) are the most abundant cell type and are involved in lipid, glycogen and calcium storage and in nutrient absorption. The F-cells play an important role in the synthesis and secretion of digestive enzymes into the lumen (Paquet et al., 1993). It is generally assumed that B- cells (secretory cells) and F- cells (fibrillar cells) types are mostly concerned with the synthesis and secretion of digestive enzymes (Gibson and Barker, 1979; Dall and Moriarty, 1983). The present study showed many alterations in the hepatopancreatic cells of $P$. clarkii after being exposed to sublethal concentrations $\left(\mathrm{LC}_{25}\right)$ of Chlorpyrifos and Azadirechtein using TEM. The TEM studies showed that Chlorpyrifos produce severe degeneration of cellular organelles including deformation of the apical surface of absorptive cell with dispersed microvilli, mitochondrial swelling with ballooned cristae, deformed cisternae of RER, lytic and vacuolated cytoplasm and pyknosis of nuclei. This finding is in agreement with Abd El-Atti (2002) and Chiodiboudet et al. (2015) who found that Mercury and Cadmium induced destructive effects on the ultrastructure of the hepatopancreas of $P$. clarkii and Palaemonetes argentines, respectively. Desouky et al. (2013) revealed severe pathological changes in hepatopancreatic cells of P. clarkia after exposure to Ethionincluding vacuolation, degeneration and distinct cellular damage; these histopathological alterations may be responsible for the high toxicity of Ethion to the crayfish. Azadirechtein causeddeformation of mitochondria with the sparce of their cisternae, fragmentation of microvilli, ruptured RER beside the presence of autophagicvacuole containing dark granules and finally bizzar nuclei having segregated nucleoli and irregular clumps of their chromatin. Similar changes were reported by Aly (2000) and Abdel-kader (2011) who demonstrated that jojoba seed oil and Neemix (Azadirechtein) caused hydropic degeneration of digestive cells of the hepatopancrease of $P$. clarkii. These changes may be attributed to direct toxic effects of toxicant on hepatopancreatic cell because it is the main site of detoxification of all type of toxins. Heterochromatin condensation and marginalization have observed in this study may be due to progressive inactivation of nuclear component (Braunbeck, 1990). Treated hepatopancreatic cells showed the presence of vesicles containing cytoplasmic debris distributed all over the cytoplasm. These vesicles probably arisen to digest the destructed cellular organelles as a result of treatment with Chlorpyrifos and Azadirechtein. Asztalos et al. (1988) proposed that the focal development of empty vacuoles might be the starting point of cellular autolysis process. The presences of autophagicvacuole in this study improve the detoxification role of hepatopancreatic cells against pesticides. The fragmentation of RER might be a consequence of final hyperactivity prior to cell necrosis (Roncero et al., 1992).Also, in the present study, mitochondrial swelling was noted in some hepatopancreatic cells 
of chlorpyrifos treated specimens. Mitochondrial swelling might be due to pollutantinduced inhibition of $\mathrm{Na}+\mathrm{H}+$ transporter and impairment of the overall osmoregulatory process of the cell (Vilella et al., 1991), thus swelling reflects the entry of solutes and water into mitochondrial matrix (Ghadially, 1985; Cheville, 1994). It can conclude that Chlorpyrifos has much toxic effect on the red swamp crayfish P. clarkii.

\section{REFERENCES}

Abd El-Atti, M.S. (2002). Effect of water quality and some parasites on some biologicalaspects of freshwater crayfish at Sharkia governorate. Ph.D. Thesis, Fac. Sci., Zagzig Univ, 152 pp.

Abdel- Kader, S.M. (2011).Some biochemical and histopathological changes in Procambarus clarkii exposed to acute toxicity of neem extract, Neemix, Abbassa, Int. J. Aqua, 4 (1):93-113.

Aly, R.H. (2000). Effect of natural and chemical insecticides on some organs of the female crayfish, Procambarus clarkii (Crustacea: Decapoda)from the RiverNile, Egypt. J. Aquat. Bio. Fish, 4 (4):83-103.

Asztalos, B.; Nemcsok, J.; Benedeczky, I.; Gabriel, R. and Szabo, A. (1988). Comparison of effects of paraquat and methidation on enzyme activity and tissue necrosis of carp following exposure to the pesticides singly or in combination. Environ. Pollut, 55: 123-135.

Barata, C.;Solayan, A. and Porte C. (2004). Role of B-esterases in assessing toxicity of OP (chlorpyrifos, malathion) and carbamate (carbofuran) pesticides to Daphnia magna. Aquat. Toxicol, 66: 125-139.

Bharathi, C. and Sandeep, B.V. (2005). Toxicity of organophosphate on edible crab Paratelphusahydrodromus. J. Ecophysiol. Occup. Hlth, 4: 247-250.

Braunbeck, T.; Burkhardt-Holm P. and Storch, V. (1990). Liver pathology in eels (Anguilla anguilla) from Rhine river exposed to the chemical spill at Basle in November 1986. Limnol.Aktuell, 1: 371-391.

Bunt, A. H. (1968). Anultrastructural study of the hepatopancreas of Procambarus clarkii (Girard) (Decapoda, Astacidea). Crustaceana, 15: 282-288.

Cheville, N.F. (1994). Ultrastructural pathology: An introduction to interpretation, 1st Ed. Ames, Iowa: Iowa State University Press, P: 67-68.

ChiodiBoudet,L.N.; Polizzi,P.;Romero,M.B.; Robles,A.;Marcovecchio, J.E. and Gerpe, M.S.(2015). Histopathological and biochemical evidence of hepatopancreatic toxicity caused by cadmium in white shrimp, Palaemonetesargentinus. Ecotoxicol. Environ. Safe, 113:231-240.

Dall, W. and Moriarty, D. J. W. (1983). Functional aspects of nutrition and digestion. The biology of Crustacea. In: Mantel LH, editor. International anatomy and physiological regulation. New York: Academic Press, 215-261.

Davis, L. E. and Bunett. A. L. (1964). A study of growth and cell differentiation in the hepatopancreas of crayfish. Devl. Biol, 10: 122-153.

Desouky, M. M. A.; Abdelawad, H. and Hegazi, B. (2013). Distribution, fate and histopathological effects of ethion insecticide on selected organ of the crayfish, Procambarus clarkii. F. Chem. Toxicol, 52:42-52.

Finney D. J. (1971). Probit analysis, 3rd Edittion. Combrige Univ. Press, London.

Ghadially, F.N. (1985). Diagnostic electron microscopy of tumours, $2^{\text {nd }}$ Edn. London: Butterworths, P: 19-62. 
Gibson, R. and Barker, P. L. (1979). The decapod hepatopancreas. Oceanogr. Mar. Bio, 7: 285-346.

Harikrishnan,R.; Rani, M. N. and Balasundaram, C. (2003). Hematological and biochemical parameters in common carp, Cyprinuscarpio, following herbal treatment for Aeromonashydrophilain fection, 221: 41-50.

Hobbs,H. H.; Jass, J. P. and Huner, J. V. (1989). A review of global crayfish introductions with particular emphasis on two North American species (Decapoda, Cambaridae). Crustaceana, 56: 299-316.

Ibrahim, A.M.; Khalil, M. T. and Mubarak, M.F. (1995). On the feeding behavior of the Exotic crayfish, $P$. clarkii in Egypt and its prospects in the bicontrol of local vector snails.J, Union.Arab. Biol., Cairo, 4:321-340.

Isman, M. B.; Koul, O.; Luczyski, A. and Kaminski, J.(1990). Insecticidal and antifeedant bioactivities of neem oils and their relationship to Azadirechtein content. J. Agric. Food. Chem, 38: 1406-1411.

Isman, M.B. (1997). Neem and other botanical insecticides: barriers to commercialization. Phytoparasitica, 25:339-344.

Jaiswal, K. and Sarojini, R. (1990). Histopathological lesion in the hepatopancrease of freshwater prawn Macrobrachium kistnensisinduced by naphthalene poisoning. Environ. pollut. Hlth. Hazards, Environmental series, III: 151-157.

Jimenez, A.; Cano, E.; Ramirez, J.L. and Ocete, M.E. (1998).Toxicidad de la azaridactina y del triclorfonsobreespecies presents en los cultivos de arroz de lasmarismas del bajo Guadalqivir. Bol San Vegas Plagas, 24:1003-1008.

Kwong, T.C. (2002). Organophosphate pesticides: biochemistry and clinical toxicology. Ther. Drug. Monit, 24: 144-149.

Lang, W.H. and Chang, V.C.S. (1967). Laboratory and field evaluation of selected pesticides for control of the red crayfish in California rice fields. Ecotoxicol. Environ, 60(2):473-477.

Lauren, D.J. and Rice, S. (1985). Significance of active in passive depuration in the clearance of naphthalene from the tissue of Hemigrapsusnudus (Crustacea: Decapod). Mar. Biol, 88:135-142.

Li,K.;Chen, L.Q.; Li, E.C. and Zhou, Z.K. (2006). Acute Toxicity of the pesticides Chlorpyrifos and Atrazine to the Chinese Mitten-handed Crab, Eriocheirsinensis. Bull. Environ. Contam. Toxico, 77: 918-924.

Mercado-Allen, R. (1991). Changes of the blood chemistry of the American lobster, HomarusamericanusH. (Milne Edwards 1837) over the moult cycle. J. Shellfish Res., 10: 147-156.

Mordue, A. J. and Blackwell, A. (1993). Azadirechtein: an update. J. Insect Physiol, 39: 903-924.

Neff, J.M.; Cox, B.A.; Dixit, D. and Anderson, J.W. (1976). Accumulation and release of petroleum derived aromatic hydrocarbons by four species of marine animals. Mar. Biol, 38:279-289.

Nicol, S.;Stolp, M. and Nordstrom, O. (1992). Changes in the gross biochemistry and mineral content accompanying the moult cycle in the Antarctic krill Euphasiasruba. Mar. Biol, 113: 201-209.

Papathanassiou, E. and King P. E. (1986). Ultrastructural changes in hepatopancreatic cells of the prawn Palaemonserratus induced by exposure to acutely toxic cadmium concentrations. Dis. Aquat. Org, 2: 39-47.

Paquet, F.; Germain, P. and Fritsch, P. (1993). Étudeultrastructurale de la glande digestive du homard Homarusgammarus. Rôle des divers types cellulairesdans les processusdigestifs. Cah. Biol. Mar, 35: 15-37. 
Rao, V.;Parvati, J.; Kavitha, K.; Jakka, P. N.M. and Pallela, R. (2005). Effect of chlorpyrifos and monocrotophos on locomotorbehaviour and acetylcholineesterase activity of subterranean termites, Odontotermesobesus. Pest. Manage. Sci, 61: 417-421.

Roncero, V.; Duran, E.; Soler, F.; Masot, J. and Gomez, L. (1992). Morphometric structural and ultrastructural studies of tench (Tincatinca L.) hepatocytes after copper sulphate administration. Environ. Res, 57: 45-58.

Rusyniak, D.E. and Nanagas, K.A. (2004). Organophosphate poisoning. Semen. Neurol, 24: 197-204.

Schaaf, O.; Jarvis, A. P.;Van Der Esch, S. A.; Giagnacovo, G. and Oldhan, N. J. (2000). Rapid and Sensitive Analysis of Azadirachtin and Related Triterpenoids from Neem (Azadirachtaindica) by Highperformance Liquid ChromatographyAtmospheric Pressure Chemical Ionization Mass Spectrometry. J. Chromat. A, 886: 89-97.

Schmutterer, H. (1995). The Neem Tree: Source of Unique Natural Products for Integrated Pest Management, Medicine, Industry and Other Purposes, VCHVerlag, Weinheim, Germany.

Scott-Fordsmand, J. J. and Depledge, M. H. (1997). Changes in the tissue concentrations and contents of calcium, copper and zinc in the shore crab Carcinusmaenas (L.) (Crustacea:Decapoda) during the moult cycle and following copper exposure during ecdysis. Mar. Environ. Res, 44: 397-414.

Singh, R.N.; Pandey, P.K.; Singh, N.N. and Dass, V.K. (2010). Acute toxicity and behavioral responses of common carp Cyprinuscarprio (Linn.) to an Organophosphate (Dimethoate). J. Zool, 5(3):183-188.

Soliman, G.N.; El-Assal, F.; El-Deen, M.S. and Hamdi, S.A.H (1998b). The reproductive biology of the red swamp crawfish $P$. clarkii (Girard, 1852) (Decapoda: Cambridae) in the River Nile, Egypt. Egypt. J. Zool, 30: 311-325.

Stanier, J. E.; Woodhouse, M. A. and Griffin, R. L. (1968). The fine structure of the hepatopancreas of Carcinusmaenas (L.) (Decapoda, Brachyura), 14: 56-66.

TrinadahaBabu, B.; Shyamasundari, K. and Hanumantha, K. (1989). Observations on the morphology and histochemistry of the mid-gut and hind-gut of Portunussanguinolentus (Herbst) (Crustacea: Brachyura). Folia. Morphol, 37: 373-381.

Tripathi, P.K.; Srivastava, V.K. and Singh A. (2000). Toxic effects of dimethoate (organophosphate) on metabolism and enzyme system of freshwater teleost fish Channapunctatus. Asian. Fis. Sci, 16:349-59.

Vilella, S.; Zonno, V.; Cassano, G.; Maffia, M. and Storelli, C. (1991). Na+/H+ exchange in the kidney of eels Anguilla anguillaadapted to sea water or to freshwater environments; studies with brush border membrane vesicles. Comp. Biochem. Physiol. C, 102: 445-560.

Wan, M.T.; Watts, R.G.; Isman, M.B. and Strub, R. (1996). Evaluation of the acute toxicity to juvenile Pacific Northwest salmon of azadirachtin, neem extract, and neem based products. Bull. Environ. Contam. Toxicol, 56: 432-439.

Wheatly, M.G. (1997). Crustacean models for studying calcium transport: the journey from whole organisms to molecular mechanisms. J. Mar. Biol. Assoc. UK., 77: 107-125.

Zilli, L.; Schiavone, R.; Scordella, G.; Zonno, V.; Verri, T.; Storelli, C. and Vilella, S. (2003). Changes in cell type composition and enzymatic activities in the hepatopancreas of Marsupenaeusjaponicus during the moulting cycle. J. Comp. Physiol. B, 173: 355-363. 

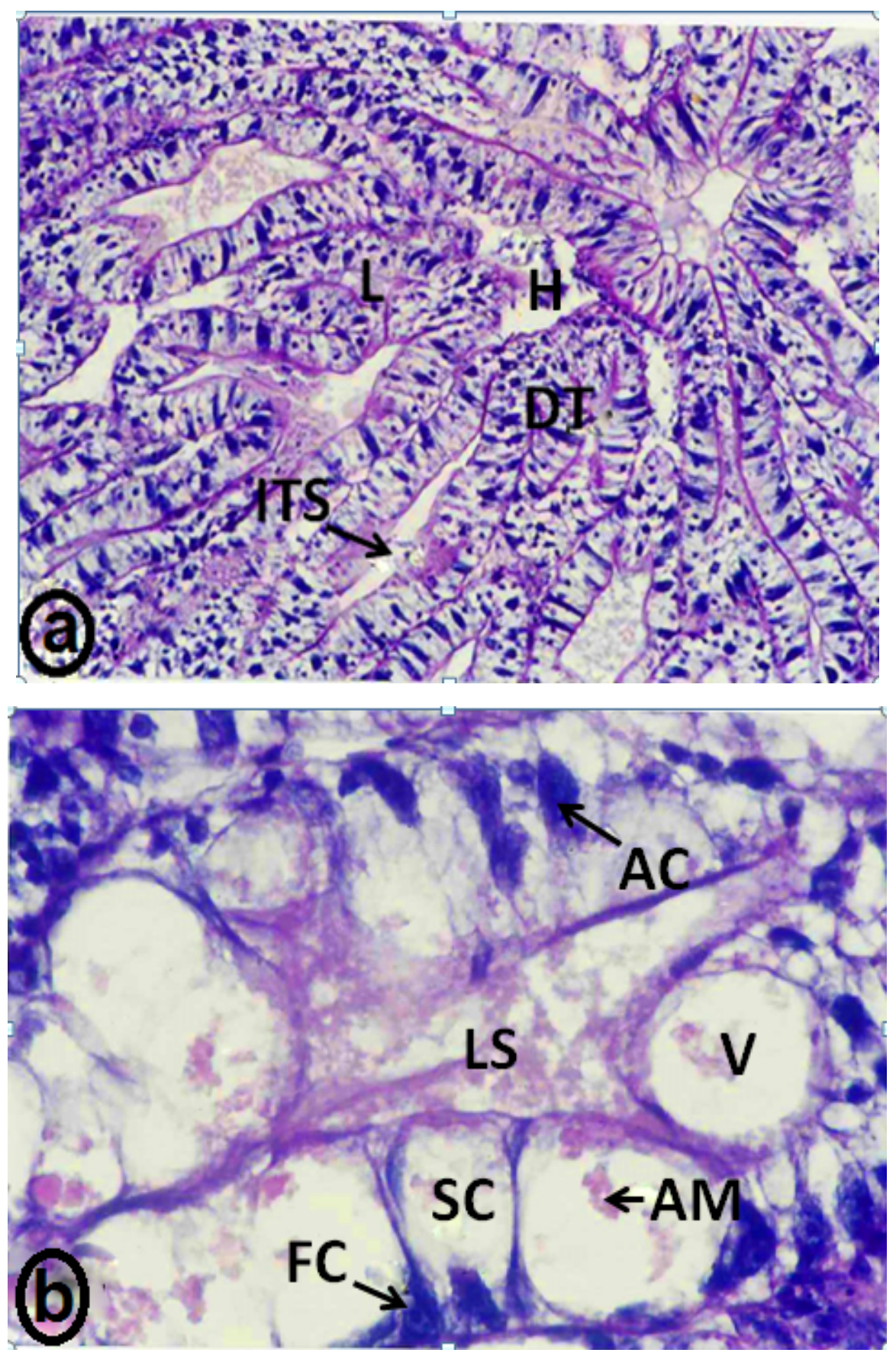

Plate I: (a-b) Histological sections of control hepatopancreas of P. clarkia (a) DT: Digestive tubules, H: Haemocyte, ITS: Intertubular space (original mag. $X=100$ ). (b) AC: Absorptive cell, AM: Acidophilic material, FC: Fibrillar cell,LS: Lumen secretion, SC: Secretory cell, V: Vacuole (original mag. $X=400$ ). 

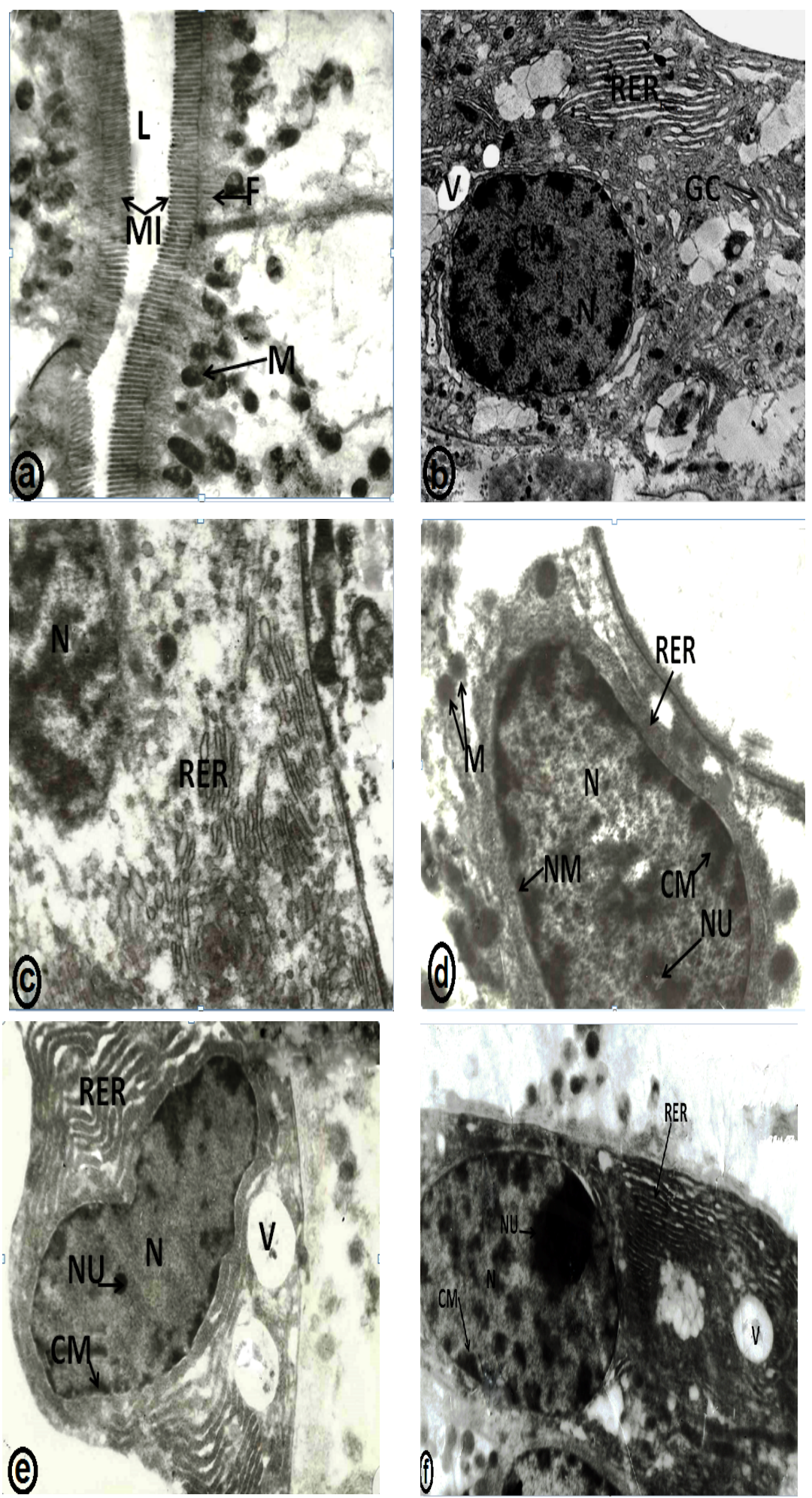

Plate II: (a) Electron micrograph showing the apical portion of control hepatopancreatic absorptive cell of $P$. clarkii. F: Filaments, L: Lumen, M: Mitochondria, MI: Microvilli (original mag. $\mathrm{X}=16000$ ).(b and c) The basal portion of control hepatopancreaticabsorptive cell, CM: Chromatin materials, G C: Golgi complex, M: Mitochondria, N: Nucleus ,RER: Rough endoplasmic reticulum,(original mag. (b) $\mathrm{X}=8000$ (c) $\mathrm{X}=28000)$.(d)Secretory cell ,CM: Chromatin material, M: Mitochondria, N: Nucleus, NU: Nucleolus, NM: Nuclear membrane, RER: Rough endoplasmic reticulum(original mag. $X=20000)$.(e and f)Fibrillar cell, CM: Chromatin materials, NU: Nucleolus, N: Nucleus, RER: Rough endoplasmic reticulum, V: vacuole (original mag. $\mathrm{X}=20000$ ). 

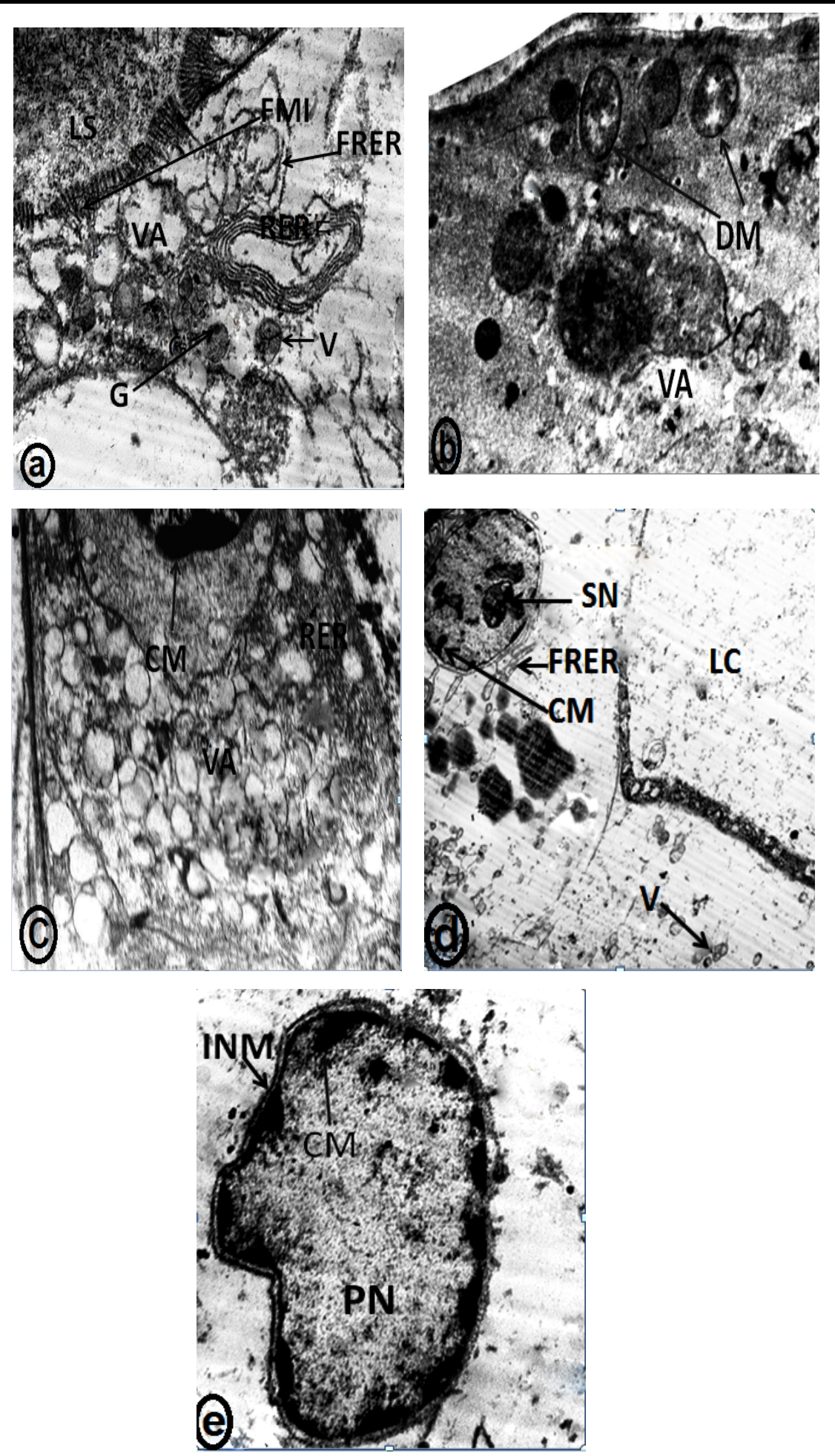

Plate III: (Fig. a) Electron micrograph showing the apical region of hepatopancreatic absorptive cell of $P$. clarkii treated with 0.0075 ppm Chlorpyrifos. DMI: Disordered microvilli, FRER: Fragmented rough endoplasmic reticulum,G: Granules, LS: Lumen secretion, RER: Concentric whorls of rough endoplasmic reticulum, V: Vesicles containing dark granules, VA: Vacuolated cytoplasm,(original mag. $\mathrm{X}=10000$ ) (b) Basal region of an absorptive cell, DM: Deformed mitochondria, VA: vacuolated cytoplasm(original mag. $X=20000)$ (c) CM: Chromatin material, $\mathrm{N}$ : Nucleus, RER: Rough endoplasmic reticulum, VA: Vacuolated cytoplasm (original mag.. $\mathrm{X}=12000$ ). (d) Secretory cell CM: Chromatin material, DM: Disordered microvilli, FRER: Fragmentedrough endoplasmic reticulum, LC: Lytic cytoplasm, SN: Segregated nucleolus V: vesicle (original mag. $\mathrm{X}=4000$ ). (e) Nucleus of hepatopancreatic absorptive cell, C: Lightened cytoplasm, CM: Chromatin material, INM: Irregular nuclear membrane, $(\mathrm{KNu})$ : Karyorrexic nucleolus, PN: Pyknotic nucleus (original mag.X=12000) 


\section{ARABIC SUMMARY}

تأثيرات الكلوربيريفوس ومستخلص بذور نبات النيم على التراكيب الظلوية للكبدالبنكرياسية لإستاكوزا المياه العذبة (بروكمبارس كلاركى الفيم)

عبدالمنعم خليل - محمود عبد العاطى سلامة ـ زينب زهزى كامل - رضوى محمد سعيد

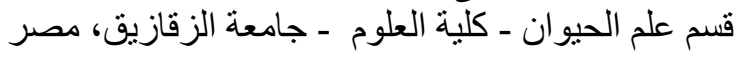

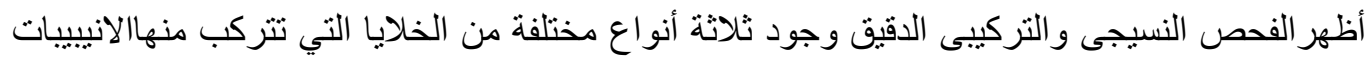

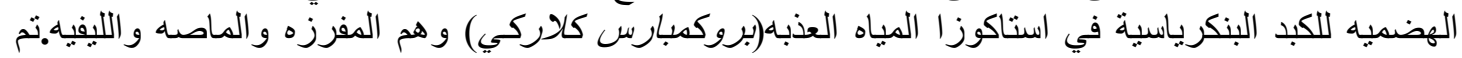

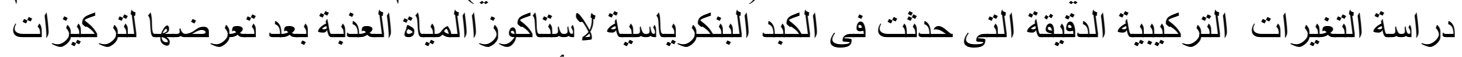

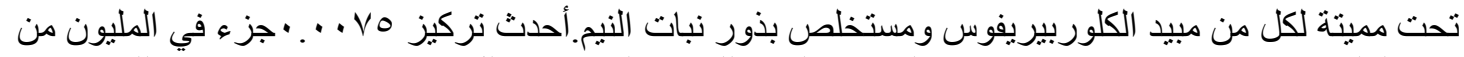

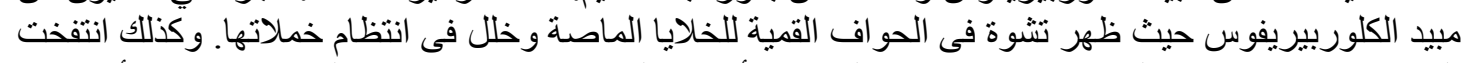

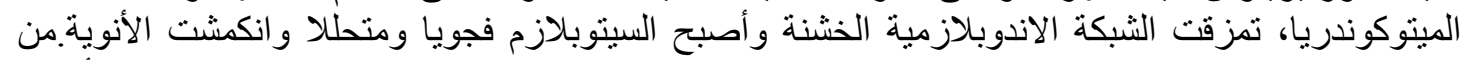

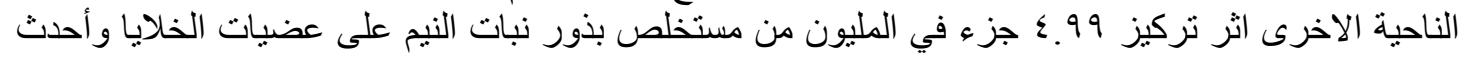

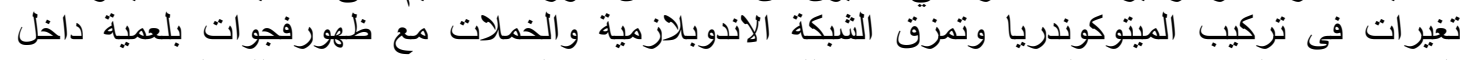

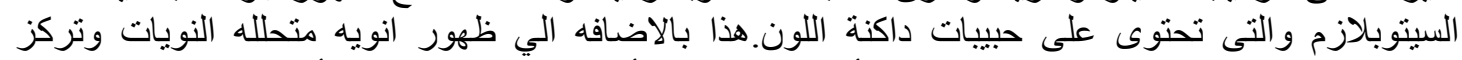

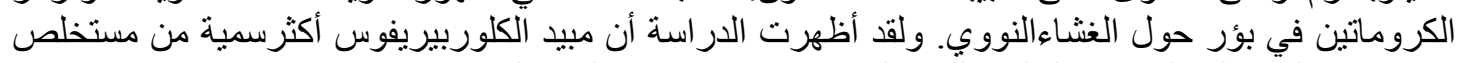
بذور نبات النيم على التركيب الخلوى للكبد البنكرياسية لاستاكوزا المياة العذبة. 